\title{
30 anos do SUS: a transição continua
}

\author{
30 years of the SUS: the transition continues
}

30 años del SUS brasileño: la transición continúa

O SUS completa os seus 30 anos em um momento de turbulência política no Brasil. O que passou, nesse período, que nos trouxe à atual situação no que concerne à saúde? O texto de Ligia Bahia nos ajuda a refletir sobre essa questão.

De saída, a autora assume uma perspectiva crítica para explicar o real como resultante da articulação entre determinantes estruturais e iniciativas, mais ou menos conscientes, dos agentes políticos em cada contexto histórico. Mais especificamente adota o binômio democracia-democratização, distinguindo a natureza do regime político do processo de sua construção. Trata-se de uma abordagem necessária e coerente com o propósito de compreender uma totalidade social para além de fenômenos imediatamente percebidos e categorizações simplistas.

Nesse esforço, a cientista produz um texto de grande densidade, em que cada parágrafo condensa uma reflexão a merecer maior desenvolvimento. Três reflexões, todavia, se destacam.

A primeira se atém às "alterações ao longo do tempo, na magnitude de cada componente [público, privado e filantrópico], nas mudanças nos relacionamentos e nas agendas politicas das três modalidades assistenciais”.

Para caracterizar essas alterações, são apresentados dados sobre produção de serviços, recursos financeiros e tipos de serviços de cada um dos componentes. Mesmo imprecisos, os dados mostram que, em 30 anos, além da expansão da oferta, as fronteiras entre público, filantrópico e privado se tornaram mais indefinidas, favorecendo a transferência de recursos do primeiro para os demais.

A segunda reflexão a ressaltar se refere aos loci institucionais de formulação das políticas de saúde. O texto evidencia a multiplicidade de instituições envolvidas no processo de construção das políticas e também a dispersão do poder de decisão. Assim, várias instâncias dos três poderes republicanos participam, mas nenhuma concentra poder suficiente para dar forma definitiva a qualquer programa de saúde. O texto mostra ainda que, em geral, essas instituições abordam os assuntos relativos à saúde de modo cético quanto à pertinência ou à viabilidade de um sistema público universal.

A terceira reflexão a destacar trata da condução setorial das políticas de saúde no período, que começa sob a influência do PCB, passa pela focalização de políticas sociais do PSDB, pela oscilação dos governos petistas entre o compromisso socialista e a aproximação com o empresariado da saúde e chega à oposição ao direito à saúde da base de sustentação do Governo Michel Temer. Ao fim das contas, o destaque é a permanente coexistência (ainda a ser aferida no Governo Temer) de avanços na implantação do SUS e de fortalecimento do setor privado.
1 Universidade Federal da Bahia, Salvador, Brasil.

Correspondência

L. E. P. F. Souza

Universidade Federal da Bahia.

Rua Basílio da Gama s/n,

Campus Universitário Canela, Salvador, $B A$ 40140-060, Brasil. luiseugenio@ufba.br 
As reflexões de Ligia Bahia levam a conclusões contundentes: (a) nenhuma das coalizões que governou o país no período foi "capaz de estabelecer regras ou de reger a disputa política"; (b) um setor privado financeirizado impôs "padrões para o uso do fundo público antidemocrático e anti-SUS"; (c) há uma "feroz competição política entre público e privado por recursos materiais e simbólicos"; (d) embora empresários da saúde proponham a ampliação do mercado para a melhoria da assistência para todos, o SUS é visto, pela maioria, como a resposta mais adequada aos problemas de saúde; (e) o rent-seeking penetrou o setor da saúde; e (f) a articulação entre um padrão de desenvolvimento democrático e democratizante não se expressou como projeto.

Dadas essas reflexões, como responder à questão inicial deste comentário?

Comparando-se 1988 e 2018, é inegável que houve expansão da oferta de serviços de saúde, com ampliação da cobertura. Essa expansão envolveu, de maneira heterogênea, os setores público, filantrópico e privado, consolidando a segmentação dos serviços entre clientelas de distintas capacidades de pagamento.

Nesse sentido, o Brasil não dispõe de um sistema de saúde - um conjunto integrado de elementos -, mas apenas de um elenco de serviços descoordenados que concorrem pelos mesmos recursos.

Esse elenco tem uma cobertura quase universal, sendo pequenos os grupos de pessoas sem nenhum acesso a ações de saúde. O tipo de "universalidade" em vigor, está claro, se afasta daquele proposto pelo Movimento da Reforma Sanitária Brasileira, inerente a um sistema único, mas é uma prova de que mudou para melhor o acesso aos serviços.

Ademais, trata-se de um elenco de serviços que reflete e reproduz as desigualdades sociais, deixando-nos distantes do projeto igualitário do Movimento da Reforma Sanitária Brasileira, mas não muito distantes das desigualdades prevalentes em 1988.

Trata-se ainda de serviços voltados para diagnóstico e tratamento de doenças e agravos, com poucas ações de promoção da saúde. Novamente, a situação em 2018 não difere muito da de 1988.

Enfim, temos um rol de serviços que abrange quase toda a população, mantém iniquidades e se centra na atenção curativa, tendo como base uma distribuição matizada das ações entre os setores público, privado e filantrópico, em que o primeiro dispõe de menos recursos materiais e simbólicos.

Essa configuração, em certa medida, pode ser vista como orgânica a uma sociedade capitalista periférica, imersa em lutas de classe. Numa perspectiva histórico-estrutural 1, pode-se pensar que, com uma atenção primária atendendo a segmentos desfavorecidos da população, assegura-se algum alívio das tensões sociais, expandindo-se, simultaneamente, o mercado para a cadeia de insumos de saúde. Ademais, a oferta privada de serviços especializados, em linha com a medicina praticada nos países centrais, atende aos anseios das classes médias, constitui um mercado para as empresas do setor, notadamente, os planos de saúde, e contribui para manter a higidez da mão de obra formalmente empregada. Por fim, alguns serviços, cujos modelos de negócio fazem com que tenham preços elevados, são diretamente financiados pelo Estado, viabilizando, por um lado, o acesso de todos e, por outro, a realização do capital da indústria de equipamentos e a oferta de opções de planos de saúde com preços suportáveis pelas classes médias.

Se essa configuração não resulta apenas do acaso, mas decorre das ações dos agentes políticos, algumas das quais se acumulam em recursos de poder ou mesmo em regras estruturais, caberia investigar os fatos e fluxos, as acumulações e as regras 2 que prevaleceram e nos trouxeram até ela.

É esse tipo de investigação que o artigo em debate faz, produzindo evidências relevantes como as que nenhum agente político teve ou tem força suficiente para impor seu projeto, ainda que o setor privado financeirizado venha sendo o mais influente, ou que o embate entre público e privado não coincide com a mera oposição entre serviços estatais e serviços particulares.

Nesse contexto, a disputa entre diferentes projetos societários permanece aberta. Mais importante, "a articulação entre um padrão de desenvolvimento democrático e democratizante" continua possível. Diria até que a experiência de inclusão social, com todas as suas limitações, vivida por amplos segmentos da população, durante os governos do PT, fortaleceu essa possibilidade.

De sua parte, o Movimento da Reforma Sanitária Brasileira segue atuante. Se não foi vitorioso na implantação de um sistema de saúde único, universal e igualitário, tampouco foi derrotado a ponto de estar fora de combate. Os avanços do SUS e as dificuldades dos agentes privatistas de convencer os cidadãos do caráter não excludente e angariar apoios para seu projeto sustentaram o Movimento. 
A turbulência política, em 2018, é sugestiva do acirramento das lutas de classes e, portanto, da emergência de múltiplas possibilidades. A transição não acabou: a luta continua!

1. Donnangelo MCF. Saúde e sociedade. São Paulo: Duas Cidades; 1976.
2. Matus C. Política, planejamento e governo. Brasília: Instituto de Pesquisa Econômica Aplicada; 1993. 